\title{
An Empirical Test of Motivation and Effect of Industrial Technology Policy in China's Electronic Information Industry
}

\author{
Yaozhong Chang \\ Institute of Industrial Economics Chinese Academy of Social Sciences \\ Beijing, China \\ yzhchang@263.net
}

\begin{abstract}
Industrial policy theory indicates that industrial policy, especially technology policy, is designed to intervene economic imbalance and reduce bottleneck to optimize resource configuration and exert economic potential, but research gap is short of empirical test. In this paper, empirical test is done to analyze relations among industrial technology policy, technicist resource and technical competitive power difference, economic development and opening-up in electronic information industry in 26 years. Test results indicate that structural technical competitive power difference and technicist resource bottleneck lead to establishment and adjustment of industrial technology policy and continuous increase of degree of opening-up both of which will raise level of economy, and improved economy will further help to promote technicist cultivation. The results support view points of industrial policy theory that industrial technology policy should intervene resource bottleneck to optimize resource configuration for purpose of exerting economic potential.
\end{abstract}

Keywords-industrial technology policy; technicist resource; technical competitive power difference

\section{INTRODUCTION}

American scholar, Chalmers Johnson considered that industrial policy is a summary of government's related activities to develop or restrict domestic industries in order to acquire global competitive power [1]. Zhou argued that industrial policy is assumption on trend and target of industrial structure variance in certain period [2]. As representative of Structuralism Economy, Chenery argued that there is no most optimized resource configuration and reassignment of resource among departments could bring economic growth [3]. Guo suggested that economic imbalance itself contains potential of accelerating development by reducing bottleneck and reassigning resource to high efficiency departments and the potential of developing countries may be larger than that of developed countries [4]. German economist, List also oppugned static comparative advantage that latecomer countries will drop behind forever and upgrade industry after advanced countries step by step, and he thought government could support domestic industries in disadvantage to gain international competitive power [5]. Jin argued that industrial technology policy is a series of policies implemented by government to promote industrial development from angle of science and technology [3].
As a forerunner and pillar industry of China, electronic information industry shows dense technology and talent, and needs great amount of devotion but has also huge external effect. Hence it is important industry for industrial technology policy to intervene. In early 1980 s, though with some industrial basis, technical level of China's electronic information industry dropped far behind that of advanced countries and shortage of engineers and scientists became bottleneck for further industrial development. For example, in 1984, proportion of technicists including engineers and scientists in all employees in this industry in China was only less than 7 percent while it was more than 40 percent in America, and production value per capita in China was less than 10 percent of that in America. Consequently, Chinese government carried out a series of industrial technology policies to promote development of electronic information industry from 1980 s to 2000 s. In 1980s, production localization policy was implemented to introduce, digest and absorb foreign technology to realize domestic production; In 1990s, independent development policy was implemented to realize domestic brand and product; In 2000s, core capacity policy was implemented to break though core and critical technology bottleneck [6]. For example, in 1980s, talent development became one strategy, devotion in universities and schools in this industry increased from 3.6 percent in sixth five-year-plan period to 10 percent in seventh fiveyear-plan period, introduction of talent was emphasized and proportion target of specialists in all employees was set to be 19.1 percent. In 1990 s, policy of four items of tax preference were put forward in which enterprises could pick up 10 percent of research and development fee from income during eighth five-year-plan period, and outlay for scientific research was increased in ninth five-year-plan period. In 2000s, scientific research institutes were transformed to be enterprises during tenth five-year-plan period [7]. Policies in those phases pushed rise of technical capacity of electronic information industry and then promoted establishment and improvement of nation's telecommunication infrastructure powerfully and continuously, which finally speeded development of national economy.

To sum up, there are close relationships among industrial technology policy, technical competitive power difference (imbalance), talent resource (bottleneck), opening-up and economic level. In this paper, econometric method is used to analyze those relationships in electronic information industry 
and parse motivation and effect of industrial technology policy.

\section{ECONOMETRIC MODEL ESTABLISHMENT}

\section{A. Variable Definition}

1) Industrial technology policy: Related phase policies in electronic information industry are adopted. It's index of strength to promote industrial technology capacity by nation's policies.

2) Technicist proportion: Proportion of engineers and scientists in all employees in this industry is adopted. It's index of state of technicist resource and technical capacity in this industry.

3) Technical competitive power difference: Value of difference between production value per capita in China and that in America divided by that in America in this industry is adopted. It's index of competition power difference between enterprises in China and those in advanced countries, and is also indicator of structural division of work in this industry between China and advanced countries.

4) Economic level: GDP per capita is adopted. It is index of economic level, and help to estimate economic potential and to foresee possible increase or decrease of resource devoted to science activity and education.

5) Degree of opening-up: Value of total export-import volume divided by GDP is adopted. It's index of degree of introducing and learning foreign technology and competing with foreign companies.

\section{B. Sample Data Selection}

1) Industrial technology policy: Index of industrial technology policy reflects strength of promotion of industrial technology capacity by policy. According to Chang's division of phases of nation's industrial technology policies, they're prophase of policy from 1976 to 1979, production localization promotion phase in 1980s, independent development promotion phase in 1990s and core capacity promotion phase in 2000s [6]. The representative events of latter three phases are introduction of public program controlled switching system (Abr. PPCSS) in Shanghai Bell China-Belgium joint-venture in 1982, appearance of Chinese independent development PPCSS by five domestic enterprises from 1991, and acceptance of TD-SCDMA three generation mobile communication standard put forward by Datang telecom as an international standard in 2001. Strength of technology promotion by policies became more and more powerful in these phases, and the strength in four phases is quantified to be 0 to 3 respectively.

2) ii) Technicist proportion: Proportion of engineers and scientists in all employees in electronic information industry from 1976 to 2001

3) Technical competitive power difference: Value of difference between production value per capita in China and that in America divided by that in America in electronic information industry from 1976 to 2001

4) Economic level: Constant GDP per capita from 1976 to 2001

5) Degree of opening-up: Value of total export-import volume divided by GDP from 1976 to 2001

Index values are shown in Fig. 1. It could be known that technical competitive power difference became lower gradually and other three indexes had trend of rising.

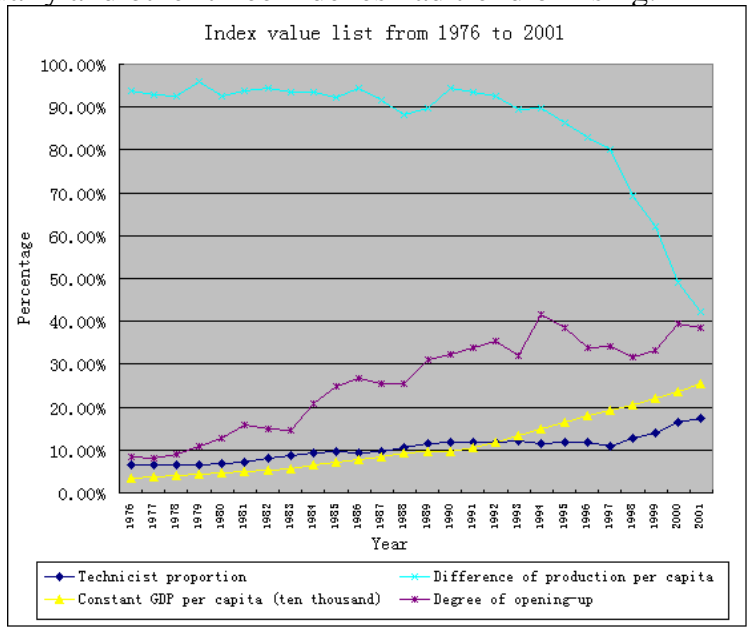

Source: China electronic industry yearbook, China statistical yearbook, China foreign economic stati stical yearbook and statistical data from National Bureau of Statistics of China

Figure 1. Index value list from 1976 to 2001

\section{Data Mode}

Granger causality test by F-test is used to analyze influence of bypast conduct of one variable on current conduct of another variable. When one variable $(\mathrm{X})$ has single-direction Granger causality influence on another variable ( $\mathrm{Y}), \mathrm{X}$ is Granger cause of $\mathrm{Y}$ [8]. If there are double-direction Granger causality influence between $X$ and $\mathrm{Y}$, there may be some factor with common effect on both $\mathrm{X}$ and Y [9]. Here Granger causality test and OLS test will be used to mainly analyze single-direction causality and character of this relation. Important double-direction causality is also analyzed as complementarity.

\section{ECONOMETRIC RESULT AND ANALYSIS}

Because of sensitivity of lag period for Granger causality test, optimized lag period should be found. Cointegration test of five variables indicate existence of cointegration relation among them. VAR (vector autoregression) model of five variables are established and lag length criteria analysis is done with result in Table I. It's found that lag of 1 is optimized choice supported by three kinds of test results and lag of 2 is secondary choice. 
TABLE I. TEST RESUlT OF OPTIMIZED LAG

\begin{tabular}{|c|c|c|c|c|c|c|}
\hline Lag & LogL & LR & FPE & AIC & SC & HQ \\
\hline 0 & -31.51 & NA & $1.65 \mathrm{e}-05$ & 3.16 & 3.42 & 3.24 \\
\hline 1 & 103.04 & $198.90^{*}$ & $1.28 \mathrm{e}-09 *$ & -6.35 & $-4.87 *$ & -5.98 \\
\hline 2 & 131.81 & 30.02 & $1.32 \mathrm{e}-09$ & -6.68 & -3.96 & $-6.00^{*}$ \\
\hline 3 & 159.58 & 16.90 & $3.48 \mathrm{e}-09$ & $-6.92 *$ & -2.97 & -5.93 \\
\hline
\end{tabular}

According to optimized and suboptimal lag choice, Granger causality test is done for each pair of variables, with F-statistics and significance level shown in Table II and III.

TABLE II. GRANGER CAUSALITy Test Result with LAG 1

\begin{tabular}{|c|c|c|c|c|c|}
\hline \multicolumn{6}{|c|}{ Granger Causality Test, Lags: 1} \\
\hline Index & DIFF & ENGP & $\mathrm{ECO}$ & OPUP & POL \\
\hline DIFF & & $\begin{array}{l}8.54 \\
* * *\end{array}$ & $\begin{array}{c}4.42 \\
* *\end{array}$ & No & $\begin{array}{c}2.80 \\
*\end{array}$ \\
\hline ENGP & No & & No & $\begin{array}{c}7.63 \\
* *\end{array}$ & $\begin{array}{l}7.95 \\
* * *\end{array}$ \\
\hline ECO & $\begin{array}{c}4.84 \\
* *\end{array}$ & $\begin{array}{c}3.87 \\
*\end{array}$ & & No & $\begin{array}{c}4.69 \\
* *\end{array}$ \\
\hline OPUP & No & No & $\begin{array}{c}2.92 \\
*\end{array}$ & & No \\
\hline POL & No & No & $\begin{array}{c}7.38 \\
* *\end{array}$ & No & \\
\hline
\end{tabular}

TABLE III. GRANGER CAUSALITy Test RESUlt With LAG 2

\begin{tabular}{|c|c|c|c|c|c|}
\hline \multicolumn{7}{|c|}{ Granger Causality Test, Lags: 2} \\
\hline Index & DIFF & ENGP & ECO & OPUP & POL \\
\hline DIFF & & $\begin{array}{c}4.37 \\
* *\end{array}$ & No & No & $\begin{array}{c}7.39 \\
* * *\end{array}$ \\
\hline ENGP & $\begin{array}{c}3.55 \\
* *\end{array}$ & & No & $\begin{array}{c}4.90 \\
* *\end{array}$ & $\begin{array}{c}3.67 \\
* *\end{array}$ \\
\hline ECO & No & $\begin{array}{c}4.07 \\
* *\end{array}$ & & No & $\begin{array}{c}5.12 \\
* *\end{array}$ \\
\hline OPUP & No & No & No & & No \\
\hline POL & No & No & $\begin{array}{c}4.51 \\
* *\end{array}$ & No & \\
\hline
\end{tabular}

TABLE IV. GRANGER CAUSALITy TeSt Result For ENGP AND DIFF WITH LAG 3

\begin{tabular}{|l|c|c|c|}
\hline \multicolumn{4}{|c|}{ Pairwise Granger Causality Tests, Lags: 3} \\
\hline Null Hypothesis: & Obs & F-Statistic & Prob. \\
\hline ENGP does not Granger Cause DIFF & 23 & 2.238 & 0.123 \\
\hline DIFF does not Granger Cause ENGP & & 2.543 & 0.093 \\
\hline
\end{tabular}

Know from Table II to IV, There are single direction Granger causality relations from technical competitive power difference (DIFF) to technicist proportion (ENGP), from technical competitive power difference (DIFF) to technology policy (POL), from technicist proportion (ENGP) to degree of opening-up (OPUP), from technicist proportion (ENGP) to technology policy (POL), from economic level (ECO) to technicist proportion (ENGP), and from degree of openingup (OPUP) to economic level (ECO). In Lag 2, technicist proportion (ENGP) also has Granger causality influence on technical competitive power difference (DIFF), but the causality disappeared in lag 3 as shown in Table IV. Hence, it's considered that technical competitive power difference (DIFF) has single direction causality influence on technicist proportion (ENGP). In addition, technology policy (POL) has double direction Granger causality relation with economic level (ECO).
Further OLS tests between each pair of variables with Granger causality relation are done with results in Table V, and variables of cause and result are explanatory variable and explained variable respectively.

TABLE V. OLS Test Result Between EAch Pair of VARIables

\begin{tabular}{|c|c|c|c|c|}
\hline $\begin{array}{c}\text { Granger } \\
\text { Causality }\end{array}$ & Coefficient & $\begin{array}{c}\text { T-Statistics } \\
\text { Significance }\end{array}$ & $\begin{array}{c}\text { Adj. } \\
\text { R-squared }\end{array}$ & $\begin{array}{c}\text { Significance of } \\
\text { residual unit root test }\end{array}$ \\
\hline DIFF to ENGP & -0.166 & $\begin{array}{c}-6.691 \\
* * *\end{array}$ & 0.636 & $* *$ \\
\hline DIFF to POL & -4.158 & $\begin{array}{c}-4.716 \\
* * *\end{array}$ & 0.459 & $* *$ \\
\hline ENGP to OPUP & 3.279 & $\begin{array}{c}9.586 \\
* * *\end{array}$ & 0.784 & $*$ \\
\hline ENGP to POL & 26.899 & $\begin{array}{c}11.942 \\
* * *\end{array}$ & 0.850 & $* * *$ \\
\hline ECO to ENGP & $3.96 \mathrm{E}-5$ & $\begin{array}{c}11.288 \\
* * *\end{array}$ & 0.835 & $* * *$ \\
\hline OPUP to ECO & 5240.89 & $\begin{array}{c}7.372 \\
* * *\end{array}$ & 0.681 & $*$ \\
\hline POL to ECO & 703.635 & $\begin{array}{c}9.215 \\
* * *\end{array}$ & 0.770 & $* *$ \\
\hline
\end{tabular}

According to Table $\mathrm{V}$, unit root test of residual time series indicate that most pair of variables exist stable cointegration relation. Second, with exception of two pair of variables for DIFF with significant negative relations, other pairs of variables show significant positive relations. The test shows following results. i) Technical competitive power difference shows notable negative influence on technicist proportion. In practice, international industrial division of work shows grads distribution of technology such as work division of high end part manufacture and assembling parts, which intensifies structural difference of technicists. ii) Technical competitive power difference and technicist proportion have negative and positive influence on technology policy respectively. In practice, great differences of technology and technicist between developing countries and developed countries in electronic information industry prompt the former's government to establish and adjust technology promotion policy. iii) Technicist proportion advances opening-up. In practice, introducing, digesting, absorbing and innovating technology from advanced countries and competing with foreign companies have been carried out continuously with one important target of cultivating local engineers and scientists. iv) Economic level has positive influence on technicist proportion. In practice, economic level improvement could bring more resource devotion on education and scientific research. v) Technology policy and opening-up have positive influence on economic level.

\section{CONCLUSION}

Empirical test result and analysis show that industrial structural imbalance (technical competitive power difference) intensifies difference of technicist resource, and the lagged status prompt government to establish and adjust 
corresponding technology policy to improve technicist resource and reduce difference of technical competitive power. And technology introduction, assimilation, absorption and innovation for purpose of improving technicist resource and market competition prompt opening-up process. Technology policy and opening-up further raise economic level greatly, which improves condition for cultivation of technicists.

In conclusion, technology policy aims conquering imbalance of technical resource configuration and technology bottleneck of developing countries. Through phase policy establishment and adjustment, technology resource is reassigned and optimized, and economic potential of developing countries is exerted. This conclusion supports view points of industrial policy theory on motivation and effect of technology policy.

\section{REFERENCES}

[1] M. Yang, "Industrial policy research", Shanghai: Shanghai Joint Publishing Company, 1989.

[2] S.-L. Zhou, "Problem exploring of industrial policy", Beijing: Economy and Management Publishing House, 1987.

[3] B. Jin, "Industrial economics (new edition)", Beijing: Economy and Management Publishing House, 2005.

[4] K.-S. Guo, "Structure optimization and economic development", Guangzhou: Guangdong Economy Publishing House, 2001.

[5] F. List, "The national system of political economy", Beijing: Commercial Press, 1983.

[6] Y.-Z. Chang, "Multiple-way effect of ownership factor in the catchup of the latecomers of enterprises in China telecom manufacturing", 2013 International Conference on Education, Management and Social Science, in press, 2013.

[7] Electronic industry yearbook compilation committee, "China electronic industry yearbook", Beijing: Publishing House of Electronic Industry, 1986-2002.

[8] Z.-N. Li and W.-Q. Pan, "Econometrics", Beijing: Higher Education Press, 2009.

[9] D.-H. Yi, "Data analysis and Eviews application", Beijing: China Renmin University Press, 2008. 